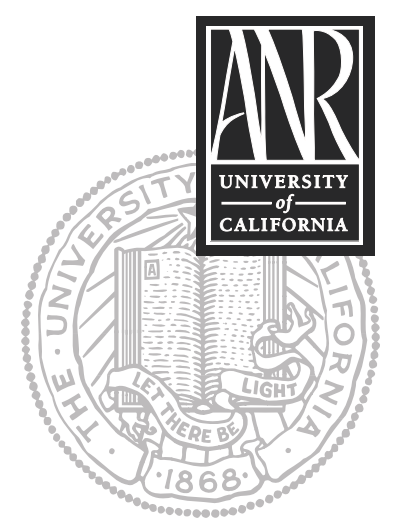

UNIVERSITY OF CALIFORNIA

Division of Agriculture and Natural Resources http://anrcatalog.ucdavis.edu

\title{
NUTRITION AND HEALTH INFO SHEET Energy Drinks
}

KARRIE HENEMAN, Assistant Project Scientist, Department of Nutrition, University of California, Davis; SHERI ZIDENBERG-CHERR, UCCE Nutrition Science Specialist, Department of Nutrition, University of California, Davis

\section{What are energy drinks?}

The term energy drink refers to a beverage that contains caffeine in combination with other ingredients such as taurine, guarana, and B vitamins, and that claims to provide its consumers with extra energy. ${ }^{1}$ This term was created by companies in the beverage industry ${ }^{1}$ and is not recognized by the United States Food and Drug Administration (FDA) or the United States Department of Agriculture (USDA).

\section{Is there evidence that these energy drinks increase energy?}

There is limited evidence that consumption of energy drinks can significantly improve physical and mental performance, ${ }^{2}$ driving ability when tired, ${ }^{3}$ and decrease mental fatigue during long periods of concentration. ${ }^{4}$ Unfortunately, the body of literature is limited and it is not known whether these improvements are due to the caffeine, other herbal ingredients, or as a result of the combination of the ingredients found in the beverage. ${ }^{2}$

\section{Can consumption of energy drinks have adverse effects?}

The caffeine content of a single serving of an energy drink (8 to $12 \mathrm{fl} \mathrm{oz}$ ) can range from 72 to $150 \mathrm{mg}$; however, many bottles contain 2 to 3 servings, raising the caffeine content to as high as $294 \mathrm{mg}$ per bottle. (See the metric conversion table at the end of this publication.) In comparison, the caffeine content per serving of brewed coffee, tea, and cola beverages ( $8 \mathrm{fl} \mathrm{oz}$ ) ranges from 134 to $240 \mathrm{mg}, 48$ to $175 \mathrm{mg}$, and 22 to $46 \mathrm{mg}$ respectively. ${ }^{5}$ A recent literature review determined that consumption of up to $400 \mathrm{mg}$ of caffeine daily by healthy adults is not associated with adverse effects. ${ }^{5}$ However, groups that are at risk, such as women of reproductive age and children, should limit their daily consumption of caffeine to a maximum of $300 \mathrm{mg}$ for the former and $2.5 \mathrm{mg} / \mathrm{kg}$ body weight for the latter; ${ }^{5}$ thus they may need to avoid consuming energy beverages with a higher caffeine content. Adolescents should also limit caffeine consumption, as intakes greater than $100 \mathrm{mg}$ per day have been associated with elevated blood pressure. ${ }^{6}$ Based on these findings, consumption of energy drinks by pregnant or nursing women, adolescents, and children is not recommended.

Caution is warranted even for healthy adults who choose to consume energy beverages. Consumption of a single energy beverage may not lead to excessive caffeine intake; however, consumption of two or more beverages in a single day can. Other stimulants such as guarana and ginseng are often added to energy beverages and can enhance the effects of caffeine. Guarana, in particular, contains caffeine ( $1 \mathrm{~g}$ of guarana is nearly equal to $40 \mathrm{mg}$ of caffeine $)^{7}$ and may substantially increase the total caffeine in an energy drink. Adverse effects associated with caffeine consumption in amounts of $400 \mathrm{mg}$ or more include nervousness, irritability, sleeplessness, increased urination, abnormal heart rhythms (arrhythmia), decreased bone levels, and stomach upset. ${ }^{5}$

Furthermore, energy drinks contain added sugar. According to the USDA Dietary 
What is the caffeine and sugar content of energy drinks?

\begin{tabular}{|l|c|c|c|c|c|}
\hline & $\begin{array}{c}\text { Serving } \\
\text { (fl oz) }\end{array}$ & $\begin{array}{c}\text { Servings per } \\
\text { container }\end{array}$ & $\begin{array}{c}\text { Sugar per } \\
\text { serving (g) }\end{array}$ & $\begin{array}{c}\text { Caffeine } \\
\text { perving } \\
\text { (mg) }\end{array}$ & Kcal \\
\hline Drink & 8 & 2 & 0 & 80 & 10 \\
\hline Diet Rockstar Energy Drink & 8 & 2 & 29 & 72 & 111 \\
\hline Full Throttle & 12 & 1 & 0 & 150 & 3 \\
\hline Go Girl Sugar Free & 8 & 3 & 3 & 80 & 10 \\
\hline Lo-Carb Monster XXL & 8 & 2 & 27 & 80 & 100 \\
\hline Monster Energy Assault & 8 & 3 & 27 & 80 & 100 \\
\hline Monster Energy XXL & 8.3 & 1 & 27 & 80 & 110 \\
\hline Red Bull & 8.3 & 1 & 0 & 80 & 10 \\
\hline Red Bull Sugar Free & 8 & 2 & 30 & 80 & 130 \\
\hline Rockstar Energy Drink & 8 & 2 & 21 & 80 & 90 \\
\hline Rockstar Juiced & 8 & 2 & 26 & 147 & 100 \\
\hline Wired 294 Caffeine & & 2 & & & \\
\hline
\end{tabular}

Note: This table does not include amounts of other stimulants found in energy drinks that can enhance the effects of caffeine.

\section{There are many unusual ingredients in energy drinks. What do they claim to do?}

\begin{tabular}{|c|c|c|}
\hline Ingredient & Drink & Functional claims \\
\hline carnitine & Monster, Rockstar, Full Throttle & $\begin{array}{l}\text { improves endurance }{ }^{14} \text {, increases fat metabolism }{ }^{15} \text {; protects } \\
\text { against cardiovascular disease }{ }^{16}\end{array}$ \\
\hline glucuronlactone & $\begin{array}{l}\text { Go Girl Sugar Free, Red Bull, } \\
\text { Monster }\end{array}$ & promotes excretion of toxins and protects against cancer ${ }^{1}$ \\
\hline guarana & Monster, Rockstar, Full Throttle & $\begin{array}{l}\text { increases energy, enhances physical performance, and promotes } \\
\text { weight loss }{ }^{18}\end{array}$ \\
\hline inositol & $\begin{array}{l}\text { Go Girl Sugar Free, Red Bull, } \\
\text { Monster, Rockstar, Wired } B_{12} \\
\text { Rush }\end{array}$ & $\begin{array}{l}\text { decreases triglyceride and cholesterol levels, lowering risk of } \\
\text { cardiovascular disease } \mathrm{e}^{13}\end{array}$ \\
\hline panax ginseng & Monster, Rockstar & $\begin{array}{l}\text { speeds illness recovery; improves mental, physical, and sexual } \\
\text { performance; controls blood glucose and lowers blood pressure }{ }^{17}\end{array}$ \\
\hline $\begin{array}{l}\text { super citramax } \\
\text { (hydroxy citric acid, garcinia } \\
\text { cambogia extract) }\end{array}$ & Go Girl Sugar Free & suppresses appetite, resulting in weight loss ${ }^{10}$ \\
\hline taurine & $\begin{array}{l}\text { Go Girl Sugar Free, Red Bull, } \\
\text { Monster, Rockstar, Full Throttle }\end{array}$ & lowers risk of diabetes ${ }^{11}$, epilepsy, ${ }^{11}$ and high blood pressure ${ }^{12}$ \\
\hline yohimbine $\mathrm{HCl}$ & VPX Redline & improves sexual performance $e^{8,9}$ and promotes weight loss ${ }^{10}$ \\
\hline
\end{tabular}

\section{Is there scientific evidence to support these claims?}

\begin{tabular}{|c|c|}
\hline Ingredient & Scientific evidence \\
\hline carnitine & $\begin{array}{l}\text { There is no clinical evidence that carnitine use is effective for increased endurance }{ }^{14} \text { or weight loss, } \\
\text { but it may protect against heart disease. }{ }^{16}\end{array}$ \\
\hline glucuronlactone & Scientific evidence does not exist to support claims regarding the efficacy of glucuronolactone. ${ }^{1}$ \\
\hline guarana & $\begin{array}{l}\text { A major component of guarana is caffeine. }{ }^{13} \text { Caffeine consumption has been associated with } \\
\text { increased energy, enhancement of physical performance, and suppressed appetite. }\end{array}$ \\
\hline inositol & Scientific evidence does not exist to support claims regarding the efficacy of inositol. ${ }^{13}$ \\
\hline panax ginseng & Scientific evidence does not exist to support claims regarding the efficacy of panax ginseng. ${ }^{17}$ \\
\hline $\begin{array}{l}\text { super citramax } \\
\text { (hydroxy citric acid, garcinia } \\
\text { cambogia extract) }\end{array}$ & There is scientific evidence that use of this supplement decreases food consumption. ${ }^{10}$ \\
\hline taurine & $\begin{array}{l}\text { Clinical evidence is insufficient to show that taurine is effective in treating diabetes or epilepsy, }{ }^{11} \\
\text { but it may lower blood pressure. }{ }^{12}\end{array}$ \\
\hline yohimbine $\mathrm{HCl}$ & $\begin{array}{l}\text { Although yohimbine } \mathrm{HCl} \text { may increase blood flow to sexual organs, there is no evidence that it } \\
\text { increases sexual arousal. }{ }^{8} \text { It may be effective at treating erectile dysfunction. }{ }^{9} \text { Currently no evidence } \\
\text { exists to support the claim that use of this supplement leads to weight loss. }{ }^{10}\end{array}$ \\
\hline
\end{tabular}




\section{Is consumption of these ingredients safe?}

\begin{tabular}{|c|c|}
\hline Ingredient & Safety \\
\hline carnitine & Insufficient data exists to establish the safety of carnitine use. ${ }^{15}$ \\
\hline glucuronlactone & $\begin{array}{l}\text { Insufficient data exists to establish the safety of glucuronolactone use at the concentrations found in } \\
\text { energy drinks. }{ }^{1}\end{array}$ \\
\hline guarana & $\begin{array}{l}\text { This substance is generally regarded as safe by the Food and Drug Administration Center for Food Safety } \\
\text { and Applied Nutrition (FDA CFSAN). }\end{array}$ \\
\hline inositol & Insoitol is generally regarded as safe (GRAS) by the Food and Drug Administration. \\
\hline panax ginseng & Insufficient data exists to establish the safety of panax ginseng use. ${ }^{17}$ \\
\hline $\begin{array}{l}\text { super citramax } \\
\text { (hydroxy citric acid, } \\
\text { garcinia cambogia } \\
\text { extract) }\end{array}$ & Insufficient data exists to establish the safety of super citramax use. ${ }^{10}$ \\
\hline taurine & Insufficient data exists to establish the safety of taurine use. ${ }^{1}$ \\
\hline yohimbine $\mathrm{HCl}$ & $\begin{array}{l}\text { Approved for use by the FDA to treat hypertension and sexual dysfunction, but over-the-counter use is } \\
\text { not recommended. }{ }^{10}\end{array}$ \\
\hline
\end{tabular}

\section{Should energy drinks be consumed before or during exercise?}

Caffeine is known to increase endurance and its use is therefore banned by the International Olympic Committee. ${ }^{19}$ Research has found consumption of caffeine prior to heavy exercise to be safe; however, the safety of consuming caffeine in combination with other herbal supplements found in energy drinks prior to or during exercise has yet to be established. ${ }^{1}$ Until the safety of this practice can be established, consumption of energy drinks prior to exercise by individuals of any age is not recommended.

\section{Should children and adolescents consume energy drinks?}

A recent survey of 78 youth (ages 11-18) found that 42.3 percent of participants consumed energy drinks; ${ }^{20}$ however, the effects of energy drink ingredients on children and adolescents has raised concern. ${ }^{13}$ In adolescents, caffeine consumption has been associated with an increase in blood pressure ${ }^{6}$ Based on the limited data regarding safety, it is not recommended that children or adolescents consume energy drinks.

\section{Is it safe to mix energy drinks with alcohol?}

A recent study investigating the effects of energy drink consumption in combination with alcohol reported that, despite not feeling intoxicated, participants performed just as poorly on objective measures of motor coordination and reaction time as they did after consumption of alcohol alone. ${ }^{21}$ In short, an individual may unknowingly overlook the debilitating effects of intoxication because of the sensation of alertness produced by an energy drink. Furthermore, both caffeine and alcohol act as diuretics, increasing the likelihood of dehydration and adverse cardiovascular effects. For these reasons, it is not recommended to consume energy drinks in combination with alcohol.

\section{REFERENCES}

1. The European Commission on Food Safety. 1999. Opinion on caffeine, taurine and D-glucurono- $\gamma$-Lactone as constituents of so-called "energy" drinks. The European Commission Web site, http://europa.eu.int/comm/food/fs/sc/scf/ out22_en.html.

2. Scholey, A. B., and D. O. Kennedy. 2004. Cognitive and physiological effects of an "energy drink": An evaluation of the whole drink and of glucose, caffeine and herbal flavouring fractions. Psychopharmacology 176:320-330.

3. Reyner, L. A., and J. A. Horne. 2002. Efficacy of a 'functional energy drink' in counteracting driver sleepiness. Physiol Behav 75:331-335. 
4. Kennedy, D. O., and A. B. Scholey. 2004. A glucose-caffeine 'energy drink' ameliorates subjective and performance deficits during prolonged cognitive demand. Appetite 42:331-333.

5. Nawrot, P., S. Jordan, J. Eastwood, J. Rotstein, A. Hugenholtz, and M. Feeley. 2003. Effects of caffeine on human health. Food Addit Contam 20:1-30.

6. Savoca, M. R., C. D. Evans, M. E. Wilson, G. A. Harshfield, and D. A. Ludwig. 2004. The association of caffeinated beverages with blood pressure in adolescents. Arch Pediatr Adolesc Med 158:473-477.

7. Finnegan, D. 2003. The health effects of stimulant drinks. Nutr Bull 28:147-155.

8. Meston, C. M., and M. Worcel. 2002. The effects of yohimbine plus L-arginine glutamate on sexual arousal in postmenopausal women with sexual arousal disorder. Arch Sex Behav 31:323-332.

9. McKay, D. 2004. Nutrients and botanicals for erectile dysfunction: Examining the evidence. Altern Med Rev 9:4-16.

10. Pittler, M. H., and E. Ernst. 2004. Dietary supplements for body-weight reduction: A systematic review. Am J Clin Nutr 79:529-536.

11. Birdsall, T. C. 1998. Therapeutic applications of taurine. Altern Med Rev 3:128-136.

12. Militante, J. D., and J. B. Lombardini. 2002. Treatment of hypertension with oral taurine: Experimental and clinical studies. Amino Acids 23:381-393.

13. Australia New Zealand Food Authority (ANZFA). 2001. Formulated caffeinated beverages. ANZFA Inquiry Report A394. Food Standards Australia New Zealand Web site, http://www.foodstandards.gov.au/standardsdevelopment/ applications/applicationa394formulatedcaffeinatedbeveragesenergydrinks/ index.cfm.

14. Brass, E. P. 2000. Supplemental carnitine and exercise. Am J Clin Nutr 72:618S-623S.

15. Saper, R. B., D. M. Eisenberg, and R. S. Phillips. 2004. Common dietary supplements for weight loss. Am Fam Physician 70:1731-8.

16. Ferrari, R., E. Merli, G. Cicchitelli, D. Mele, A. Fucili, and C. Ceconi. 2004. Therapeutic effects of L-carnitine and propionyl-L-carnitine on cardiovascular diseases: A review. Ann N Y Acad Sci 1033:79-91.

17. Ernst, E. 2002. The risk-benefit profile of commonly used herbal therapies: Ginkgo, St. John's wort, ginseng, echinacea, saw palmetto, and kava. Ann Intern Med 136:42-53.

18. USDA (United States Food and Drug Administration). 1994. Adverse events with ephedra and other botanical dietary supplements. FDA Medical Bulletin. Center for Food Safety and Applied Nutrition Web site, http://www.cfsan.fda. gov/ dms/ds-ephe2.html.

19. Clarkson, P. M. 1996. Nutrition for improved sports performance: Current issues on ergogenic aids. Sports Med 21:393-401.

20. O’Dea, J. A. 2003. Consumption of nutritional supplements among adolescents: Usage and perceived benefits. Health Educ Res 18:98-107.

21. Ferreira, S. E., M. T. de Mello, S. Pompeia, and M. L. de Souza-Formigoni. 2006. Effects of energy drink ingestion on alcohol intoxication. Alcohol Clin Exp Res 30:598-605. 
Metric Conversions

\begin{tabular}{|l|l|l|l|}
\hline English & $\begin{array}{l}\text { Conversion factor for } \\
\text { English to Metric }\end{array}$ & $\begin{array}{l}\text { Conversion factor for } \\
\text { Metric to English }\end{array}$ & Metric \\
\hline grain & 64.80 & 0.015 & milligram (mg) \\
\hline fluid ounce (fl oz) & 29.57 & 0.034 & milliliter (ml) \\
\hline ounce (oz) & 28.35 & 0.035 & gram (g) \\
\hline
\end{tabular}

\section{FOR FURTHER INFORMATION}

To order or obtain printed ANR publications and other products, visit the ANR Communication Services online catalog at http://anrcatalog.ucdavis.edu. You can also place orders by mail, phone, or FAX, or request a printed catalog of our products from:

Agriculture and Natural Resources

Communication Services

6701 San Pablo Avenue, 2nd Floor

Oakland, California 94608-1239

Telephone: (800) 994-8849 or (510) 642-2431

FAX: (510) 643-5470

E-mail inquiries: danrcs@ucdavis.edu

An electronic version of this publication is available on the ANR Communication Services Web site at http://anrcatalog.ucdavis.edu.

This publication has been anonymously peer reviewed for technical accuracy by University of California scientists and other qualified professionals. This review process was managed by the ANR Associate Editor for Food and Nutrition.

Publication 8265

ISBN-13: 978-1-60107-487-4

(C) 2007 The Regents of the University of California

Division of Agriculture and Natural Resources

All rights reserved.

No part of this publication may be reproduced, stored in a retrieval system, or transmitted, in any form or by any means, electronic, mechanical, photocopying, recording, or otherwise, without the written permission of the publisher and the authors.

The University of California prohibits discrimination or harassment of any person on the basis of race, color, national origin, religion, sex, gender identity, pregnancy (including childbirth, and medical conditions related to pregnancy or childbirth), physical or mental disability, medical condition (cancer-related or genetic characteristics), ancestry, marital status, age, sexual orientation, citizenship, or status as a covered veteran (covered veterans are special disabled veterans, recently separated veterans, Vietnam era veterans, or any other veterans who served on active duty during a war or in a campaign or expedition for which a campaign badge has been authorized) in any of its programs or activities. University policy is intended to be consistent with the provisions of applicable State and Federal laws.

Inquiries regarding the University's nondiscrimination policies may be directed to the Affirmative Action/Staff Personnel Services Director, University of California, Agriculture and Natural Resources, 1111 Franklin Street, $6^{\text {th }}$ Floor, Oakland, CA 94607-5201, (510) 987-0096. For information about ordering this publication, telephone 1-800-994-8849.

pr-6/07-LR/CM 